\title{
Record Link Identifier
}

National Cancer Institute

\section{Source}

National Cancer Institute. Record Link Identifier. NCI Thesaurus. Code C117050.

A sequence of characters used as a linkage between related records. 